\title{
Current concepts related to the diagnosis and treatment of hemangioma: literature
}

\section{review}

Conceitos atuais relacionados ao diagnóstico e tratamento do hemangioma: revisão da literatura

Conceptos actuales relacionados con el diagnóstico y tratamiento del hemangioma: revisión de la

literatura

Received: 01/14/2021 | Reviewed: 01/18/2021 |Accept: 01/19/2021 | Published: 01/24/2021

Igor Jose de Oliveira Campos ORCID: https://orcid.org/0000-0001-9826-4642 Federal University of Rio Grande do Norte, Brazil E-mail: igorjcampos@ufrn.edu.br

Eros Ruan de Medeiros

ORCID: https://orcid.org/0000-0003-3750-6649

Federal University of Rio Grande do Norte, Brazil E-mail: erosruan70@gmail.com

Evaldo Henrique Pessoa da Costa ORCID: https://orcid.org/0000-0001-7783-0318 Federal University of Rio Grande do Norte, Brazil E-mail: evaldopessoa@ufrn.edu.br

João Victor Freire de Paula

ORCID: https://orcid.org/0000-0001-8058-3266 Federal University of Rio Grande do Norte, Brazil E-mail: jvictorrf@ufrn.edu.br Luis Gustavo Xavier

ORCID: https://orcid.org/0000-0002-0043-1666 Federal University of Rio Grande do Norte, Brazil E-mail: 1.gxavier3@gmail.com

Cristianne Kalinne Santos Medeiros ORCID: https://orcid.org/0000-0003-2439-2523 Federal University of Rio Grande do Norte, Brazil E-mail: cristiannekalinne@gmail.com

Jabes Gennedyr da Cruz Lima ORCID: https://orcid.org/0000-0001-7420-7686 Federal University of Rio Grande do Norte, Brazil E-mail: jabes.gennedyr@hotmail.com

\begin{abstract}
Hemangioma is a tumor considered histologically benign of mesenchymal origin, characterized by the formation of vascular endothelial cells and can be divided into two types, capillary and cavernous, depending on the dominant microscopic size of the vessels. Therefore, the aim of the present study was to analyze what exists in the specialized literature on the diagnosis and treatment of hemangioma. This study was carried out based on bibliographic research, in the respective databases: Pubmed and CAPES Periodicals between the years 2011 and 2020. The research was carried out at DeCS (Health Sciences Descriptors) to choose the descriptors: "Oral Pathology"; "Diagnosis" and "Vascular Malformations". Ten scientific productions that met the inclusion criteria and were selected. The diagnosis of hemangioma, except in intraosseous cases, can be easily established in a simple and safe way through anamnesis, clinical examination and through semi-technical maneuvers, such as vitro pressure, in most cases this maneuver is conclusive. Because it is a vascular lesion, incisional biopsy is contraindicated in these cases, due to the great risk of bleeding.
\end{abstract}

Keywords: Oral pathology; Diagnosis; Vascular malformations.

\section{Resumo}

O hemangioma é um tumor considerado histologicamente benigno de origem mesenquimal, caracterizado pela formação de células endoteliais vasculares e podem ser divididos em dois tipos, capilares e cavernosos, dependendo do tamanho microscópico dominante dos vasos. Portanto, o objetivo do presente estudo foi analisar o que existe na literatura especializada sobre o diagnóstico e tratamento do hemagioma. Este estudo foi realizado com base em pesquisa bibliográfica, nas respectivas bases de dados: Pubmed e Periódicos CAPES entre os anos de 2011 e 2020. A pesquisa foi realizada no DeCS (Descritores em Ciências da Saúde) para escolha dos descritores: "Oral Pathology"; 
"Diagnóstico" e "Malformações Vasculares". Dez produções científicas que atenderam aos critérios de inclusão e foram selecionadas. $\mathrm{O}$ diagnóstico do hemangioma, exceto nos casos intraósseos, pode ser facilmente estabelecido de forma simples e segura por meio da anamnese, do exame clínico e através de manobras semiotécnicas, a exemplo da vitropressão, na maioria dos casos esta manobra é conclusiva. Por se tratar de uma lesão vascular, a realização de biópsia incisional está contraindicada nestes casos, devido ao grande risco de apresentar hemorragia.

Palavras-chave: Patologia bucal; Diagnóstico; Malformações vasculares.

\section{Resumen}

El hemangioma es un tumor considerado histológicamente benigno de origen mesenquimatoso, caracterizado por la formación de células endoteliales vasculares y puede dividirse en dos tipos, capilar y cavernoso, dependiendo del tamaño microscópico dominante de los vasos. Por tanto, el objetivo del presente estudio fue analizar lo que existe en la literatura especializada sobre el diagnóstico y tratamiento del hemagioma. Este estudio se realizó a partir de una investigación bibliográfica, en las respectivas bases de datos: Publicaciones periódicas Pubmed y CAPES entre los años 2011 y 2020. La investigación se realizó en DeCS (Descriptores de Ciencias de la Salud) para elegir los descriptores: "Patología Oral"; "Diagnóstico" y "Malformaciones vasculares". Diez producciones científicas que cumplieron con los criterios de inclusión y fueron seleccionadas. El diagnóstico de hemangioma, salvo en casos intraóseos, puede establecerse fácilmente de forma sencilla y segura mediante anamnesis, exploración clínica y mediante maniobras semitécnicas, como la presión vitro, en la mayoría de los casos esta maniobra es concluyente. Por tratarse de una lesión vascular, la biopsia incisional está contraindicada en estos casos, debido al gran riesgo de sangrado.

Palabras clave: Patología bucal; Diagnóstico; Malformaciones vasculares.

\section{Introduction}

Clinically, hemangiomas are flat or elevated lesions, with a smooth or nodular surface and in relation to their color, they can be red, purple, blue or bluish-red depending on the location, depth and invasion in the tissue and the degree of congestion of the tissue. The affected area, in relation to its size, varies from millimeters to centimeters in diameter (Costa, 2011; Dantas, 2020).

Hemangioma is characterized by being an asymptomatic lesion and can also be diagnosed through radiographic exams. Regarding the imaging features, these lesions will appear as a rounded radiotransparent image, unilocular cystic radiolucency, vertical striations in lytic foci. The radiographic characteristics obtained by imaging exams will allow a thorough examination of the lesion and its extension (Fernandes, 2018; Gomes, 2019).

The complementary semiology in the evaluation of a hemangioma may include an image study by computed tomography, magnetic resonance, angioresonance or arteriography (Palma, 2016; Neves, 2018). In relation to the treatment of this pathology, factors such as size and location of the lesion must always be taken into account when establishing the treatment (Queiroz, 2014; Sales, 2015). Thus, the aim of the present study was to analyze what exists in the specialized literature on the diagnosis and treatment of hemangioma.

\section{Methodology}

This study was carried out and based on bibliographic research, in the respective databases: Pubmed and CAPES Periodicals between the years 2011 and 2020. The inclusion criteria used were texts available online published in English and Portuguese. Research was carried out in the DeCS (Health Sciences Descriptors) to choose the descriptors: "Oral Pathology"; "Diagnosis" and "Vascular Malformations". Then, the titles were selected by the summary and by relevance in the results of the research, being excluded from the study the documents unavailable for access in full, texts not relevant to the indicated subject, as well as those that were outside the established time limit. Ten scientific productions that met the inclusion criteria and were selected. Subsequently, through the recognition, selection and ordering of the information in the documents, the process of reading the material was carried out, enabling understanding and understanding in relation to what the author affirms with the problem to which the answer is aimed. 


\section{Results and Discussion}

Hemangioma is a tumor considered histologically benign of mesenchymal origin, characterized by the formation of vascular endothelial cells and can be divided into two types, capillary and cavernous, depending on the dominant microscopic size of the vessels (Costa, 2011; Dantas, 2020). Capillary hemangioma contains capillaries of endothelial origin and includes an abnormal growth of small blood vessels, it can be immobile or pediculated, it is a soft, smooth or irregular tumor, it is usually painless, if it is not exacerbated (Queiroz, 2014; Sales, 2015).

On the other hand, cavernous hemangioma is defined as being a benign vascular neoformation of congenital origin, characterized by the formation of large channels and vascular spaces filled with blood. The cavernous form of the hemangioma is less frequent in relation to the capillary hemangioma, yet histologically they present as spongy, bluish-red, well-delimited masses, without capsule and formed by large cavernous vascular spaces filled with blood, partially or completely, are separated small amount of connective tissue. This form of hemangioma usually involves deep structures and does not usually regress, the development of these lesions is characterized by a generally slow growth (Silva, 2014; Silva, 2020).

The diagnosis of hemangioma, except in intraosseous cases, can be easily established in a simple and safe way through anamnesis, clinical examination and through semi-technical maneuvers, such as vitro pressure, in most cases this maneuver is conclusive. Because it is a vascular lesion, incisional biopsy is contraindicated in these cases, due to the great risk of bleeding (Queiroz, 2014; Silva, 2014; Silva, 2020).

The maneuver of vitro pressure is an important auxiliary exam when establishing the differential diagnosis, this maneuver is performed with the aid of a glass slide, which is properly pressed on the lesion, making it pale after its compression. This situation occurs due to the emptying of the blood vessels that form the hemangioma. Other lesions such as bruises retain their color, due to the blood tissue not being inside the vessels. Thus, it is possible to establish the diagnosis without the need for a biopsy (Fernandes, 2018; Gomes, 2019).

Magnetic resonance imaging promotes excellent tissue differentiation, it is very useful when analyzing the amplitude of arteriovenous malformations, as well as the degree of invasion of the affected structures and intra-tumor venous flow. Regarding computed tomography, it can be particularly useful in the evaluation of intraosseous lesions, as it will provide a good quality image that will allow the best evaluation of the size and condition of the lesion (Costa, 2011; Dantas, 2020). Hemangiomas observed through CT have as characteristics, masses with attenuations resembling soft tissues and in the case of intraosseous hemangioma, this presents with a mixed aspect, radiodense with radiotransparent (Fernandes, 2018; Gomes, 2019; Dantas, 2020).

Surgery is considered the treatment of choice in some specific cases, however, complete excision of the lesion can be a difficult procedure, due to the proximity of vital structures, which could cause high surgical morbidity, and present great difficulties for the execution of possible subsequent treatments (Queiroz, 2014; Silva, 2014; Gomes, 2019; Silva, 2020).

Sclerotherapy has been widely used due to its great advantages and the fact that it does not cause external scarring, in addition to promoting low morbidity and minor post-treatment complications when compared to surgical excision. The success of sclerotherapy is the result of the extensive contact of the sclerosing agent with the endothelial lining of the vessel. Consequently, sclerotherapy is more effective when the vascular space is small or when the blood flow is slow (Fernandes, 2018; Gomes, 2019).

Monoethanolamine oleate is a salt produced by the association of oleic acid and ethanolamine with hemostatic properties. This drug acts by causing local clotting by activating the Hageman clotting factor. Ethanolamine causes the formation of a fibrin clot through the chelation of calcium. The influence of both substances allows a hemostatic balance. Consequently, bleeding is prevented after its application to vascular lesions. It is possible to observe that the lesions treated 
with this agent undergo the replacement of blood vessels by connective tissue due to the inflammatory process caused by the drug (Silva, 2014; Fernandes, 2018; Silva, 2020).

One of the advantages reported by so-and-so in the application of the compound consists in the eradication of surgical trauma, providing the lowest risk of bleeding for the patient. However, it is worth mentioning that there are contraindications, they include hypersensitivity, non-compensated diabetes mellitus, areas of secondary infections and pregnant women. The concentration of the sclerosing agent does not influence the outcome of the treatment, despite this, the dose of the drug must be equivalent to the size of the lesion. When the lesion is extensive, administration of the agent should be performed in intercalated sessions of at least seven days, without exceeding 2ml in each application (Fernandes, 2018; Gomes, 2019; Silva, 2020).

The administration of the sclerosing agent should be applied slowly and gradually, trying to avoid the rupture of blood vessels. During the application of the drug, a local discomfort may occur, and soon after the patient will be able to report the burning sensation. The application of the sclerosing agent cannot be superficial, it is interesting that the operator can apply it inside the vessel, so that an extravascular inflammatory response does not occur, because if this situation occurs, it may cause necrosis of the adjacent tissues (Palma, 2016; Neves, 2018).

\section{Conclusion}

Hemangioma is a pathology that affects the head and neck region, which is complex and difficult to resolve if the diagnosis and treatment are not well established and indicated. There are many techniques for the treatment of this lesion, sclerotherapy is undoubtedly a viable treatment, very effective and satisfactory. However, it is noteworthy that it is necessary to have prior knowledge of the patient's health, the indications and contraindications of this technique. This method must be surrounded by all the necessary care and assessments as any other procedure.

\section{References}

Costa, J. R. S. (2011). Sclerotherapy for Vascular Malformations inthe Oral and Maxillofacial Region: Treatment and Follow-Upof 66 Lesions. J Oral Maxillofac Surg. 69, 88-89.

Dantas, F. S. B. (2020). Fotocoagulação a laser de diodo para tratamento de alteração vascular em lábio: relato de caso. Archives of health investigation. 9(5): 433-438.

Fernandes, D. (2018). Benign oralvascular lesions treated by sclerotherapy with ethalomine oleate: A retrospective study of 43 patients. Med. Oral Patol. Oral Cir. Bucal. 23: 181-185.

Gomes, J. A. (2019). Escleroterapia como tratamento conservador para hemangioma oral: relato de caso. Revista de Ciências Médicas e Biológicas. 18(3): 421-424.

Neves, L. (2018). Lesões vasculares orais: avaliações clínicas, diagnósticas e terapêuticas. Revista Cubana de Estomatologia. 55: 3 -4.

Palma, F. (2016). Escleroterapia de hemangioma oral: relato de caso. Salusvita. 59: 85-87.

Queiroz, S. (2014). Tratamento de hemangioma oral com escleroterapia: relato de caso. J Vas Bras. 13: 250-251.

Sales, P. (2015). Utilização de agente esclerozante no tratamento de hemangioma língua: relato de caso. Rev. Odontol. Univ. Cid. São Paulo. $27:$ 254-255.

Silva, W. B. (2014). Oral capillary hemangioma: A clinical protocol of diagnosis and treatment in adults. Oral Maxillofac Surg. 4: $231-237$.

Silva, E. L. C. (2020). Tratamento de hemangioma em mucosa labial porescleroterapia-Relato de caso clínico. Revista da Faculdade de Odontologia de Porto Alegre. 61(1): 115-122. 